\title{
A Nova Discriminação de Rendas na Constituição Federal
}

\section{Prof. Chagas Melo}

\begin{abstract}
A
discriminação de rendas visando assegurar aos três niveis de govêrno recursos para fazer face às necessidades administrativas, tem sido feita, a partir da República, na própria Constituição Federal.
\end{abstract}

Em nossa primeira Constituição, outorgada pelo Imperador D. Pedro I, em 1824, não havia discriminação de rendas, uma vez que tôdas as despesas eram feitas pelo Govêrno central em face da não existência de autonomia provincial.

O artigo 171 da Constituição do Império prescrevia:

“Tôdas as contribuições diretas, à exceção daquelas que estiverem aplicadas aos juros e amortizações da dívida pública, serão anualmente estabelecidas pela Assembléia Geral, mas continuarão até que se publique a sua derrogação, ou sejam substituídas por outras".

O Ato Adicional de 1834, descentralizando o sistema político e administrativo do Império e reconhecendo o direito das Assembléias Legislativas Provinciais de legislarem sôbre a fixação das despesas provinciais e municipais e, conseqüentemente, sôbre os impostos, determinaria a necessidade de uma discriminaçãó de rendas que veio, por fôrça da Lei $n^{\circ} 99$, de 31 de outubro de 1835 especificando apenas os impostos gerais, deixando o campo remanescente à livre concorrência das Provincias e Municípios.

$\mathrm{Na}$ Constituição de 1891 , separou-se, pela primeira veż, o campo de incidência dos governos federal e estadual, competindo ao primeiro a cobrança de impostos sôbre:

a) importação de mercadorias de procedência estrangeira;

b) consumo;

c) renda e proventos de qualquer natureza;

d) vendas e consignações. 
Aos Estados pertenciam os seguintes impostos:

a) exportação;

b) territorial;

c) transmissão de propriedade;

d) indústria e profissão.

Os demais impostos, não especificados acima, ficaram na competência dos Municipios, bem como o impôsto predial e taxas de serviços municipais que eram cobrados indistintamente, confundindo-se o conceito de impôsto com o de taxa, deixando as comunas brasileiras sem fonte de renda produtiva para custear os serviços municipais.

A Constituição de 1934 reforçou as finanças estaduais e municipais, delimitando o campo de incidência dos Municípios e transferindo aos Estados o impôsto de vendas e consignações.

O artigo 13 da Carta Magna de 1934 deferiu aos Municipios os seguintes impostos:

a) territorial urbano;

b) predial;

c) licença;

d) diversões públicas;

e) cedular sôbre renda dos imóveis rurais.

Cabiam-lhe, ainda, de acôrdo com o artigo $8^{\circ}$, $\$ 2$ e $\S 10$ do mesmo diploma legal, metade da arrecadação geral do impôsto de indústria e profissão e $20 \%$ do produto de quaisquer novos impostos que viessem a ser criados pela União ou pelos Estados.

A Constituição outorgada em 1937 manteve, em linhas gerais, a discriminação de rendas da Carta de 1934, suprimindo, entretanto, o impôsto cedular sôbre a renda dos imóveis rurais e a participação dos Municipios na arrecadação dos novos impostos.

No regime de discriminação de rendas da Constituição de 1946, foram muito beneficiados os Municipios, não sòmente com a transferência definitiva do impôsto de indústrias e profissões, como atribuindo-lhes competência, para criar novos tributos sendo o mais importante dêsses atos o que é expresso no chamado impôsto do sêlo.

A discriminação de rendas vigorou até 1951, quando foi promulgada a Emenda Constitucional $n^{\circ} 5$, modificando vários artigos referentes à competência para cobrança de impostos por parte dos Estados e Municípios, nos seguintes têrmos:

a) a Uniăo entregará aos Municipios dez por cento do toial do impôsto do consumo, fazendo-se o pagamento de modo inte- 
gral de uma só vez, a cada municipio, durante o quarto trimestre de cada ano;

b) receberão, ainda, os Municípios $15 \%$ do total que a União arrecadar do impôsto de renda, feita a distribuição em partes iguais, devendo o pagamento de cada Municipio ser feito integralmente, de uma só vez, durante o terceiro trimestre de cada ano.

Pela Emenda Constitucional $n^{\circ} 5$, os Estados perderam o impôsto territorial rural e o impôsto de transmissão inter-vivos que passaram para os Municipios.

Para permitir a reforma agrária já baixada em lei especial, a Emenda Constitucional $n^{\circ} 10$ transferiu para a competência da União a cobrança do impôsto territorial rural, determinando, porém, que o produto da arrecadação fôsse entregue aos Municipios onde estejam localizados os imóveis sôbre os quais incide a tributação, não alterando, porém, a essência da Emenda n ${ }^{\circ} 5$ que instalou no Brasil uma nova discriminação de rendas muito mais complicada do que a existente no texto original da Constituição de 1946.

A Comissão do Ministério da Fazenda, que elaborou a reforma do sistema tributário brasileiro, consubstanciado na Emenda $\mathrm{n}^{9} 18$, esclareceu em seu Relatório o segurinte: "os que lidam com os problemas financeiros da União, nos Estados e Municípios são acordes no imperativo de um reexame dos impostos da Federação, com o fim de instituir-se um sistema compativel com os requisitos do progresso econômico do País. A multiplicidade e a acumulação de incidências tributárias, a despeito da separação formal dos impostos, dificultam e oneram a produção."

Desde 1891, continua a Comissão, vem sendo seguido o critério de partilhar tributos designados por suas denominações jurídicas usuais, pôsto que nem sempre pacificas para os próprios juristas. Esse sistema tem provocado ou facilitado distorções econômicas que o crescimento das necessidades financeiras do poder público, e a conseqüente complexidade e onerosidade dos tributos federais, estaduais e municipais sòmente tendem a agravar. Exemplo desta afirmativa é a proliferação de figuras tributárias concebidas em têrmos juridico-formais com que os três governos têm procurado alargar o campo de suas incidências e fortalecer o montante de suas arrecadações. Isto sem falarmos nas sobreposições de tributos, do mesmo ou do outro poder, econômicamente idênticos e disfarçados apenas pelas roupagens juridicas de que o legislador os reveste. Pode-se, mesmo, dizer, sem exagêro, que existem hoje, no Brasil, mais tributos formalmente distintos que fatôres econômicos aptos a servir de base à tributação.

Concluindo, salienta a Comissão que "é uma redistribuição de receita fiscal que se impõe, não sòmente por motivos de segurança 
nacional mas, igualmente em favor dêsses próprios contribuintes em têrmos estritamente financeiros, uma vez que pela redistribuição da receita fiscal se consegue generalizar e, conseqüentemente, intensificar o progresso econômico e social em todo o País."

Pela Emenda Constitucional n̊ 18, os impostos componentes do sistema tributário nacional classificam-se em:

a) impostos sôbre o comércio exterior;

b) impostos sôbre o patrimônio, a renda e os ganhos de capital;

c) impostos sôbre a produção e a circulação;

d) impostos especiais sôbre produção, importação, circulação, distribuição ou consumo de combustiveis liquidos ou gasosos de qualquer natureza, produção, importação, distribuição ou consumo de energia elétrica e produção, circulação ou consumo de minerais do Pais.

São de competência da União:

a) impôsto sôbre importação;

b) impôsto sôbre exportação;

c) propriedade territorial rural;

d) renda e proventos de qualquer natureza;

e) sôbre produtos industrializados;

f) operações de crédito, câmbio, seguro, e sôbre operações relativas a titulos e valôres mobiliários;

g) sôbre serviços de transporte e conlunicações, salvo os de natureza estritamente municipal;

h) produção, circulação, importação, distribuição ou consumo de combustiveis e lubrificantes líquidos ou gasosos de qualquer origem ou natureza;

i) produção, importação, distribuição ou consumo de energia elétrica;

j) produção, circulação ou consumo de minerais do País.

Aos Estados, competem os seguintes impostos:

a) impôsto sôbre transmissão, a qualquer titulo, de bens imóveis por natureza ou por acessão fisica, como definidos em lei, e de direitos reais sôbre imóveis, exceto os direitos reais de garantia, não podendo a aliquota do imposto exceder aos limites fixados em Resolução do Senado, nos têrmos do disposto em lei complementar;

b) impôsto sôbre operações relativas à circulação de mercadorias, realizadas por comerciantes, industriais e produtores. 
não podendo a aliquota do impôsto exceder, nas operações que as destinem a outros Estados, os limites fixados pelo Senado, nos têrmos do disposto em lei complementar;

c) taxas de seus serviços;

d) contribuição de melhoria;

e) participação na arrecadação do impôsto de renda incidente sôbre a renda das obrigações de sua divida pública e sôbre os proventos dos seus servidores e das suas autarquias; trializados;

f) participação de $10 \%$ no impôsto sôbre produtos indus-

g) participação respectivamente de $60 \%$ e $90 \%$ dos impostos sôbre combustiveis e energia elétrica e por último do impôsto sôbre minerais, arrecadados nos respectivos territórios.

São dos Municipios:

a) impôsto sôbre a propriedade predial;

b) impôsto sôbre a propriedade territorial urbana;

c) impôsto sôbre serviços de qualquer natureza não compreendidos na competência tributária da União e dos Estados;

d) participação na arrecadação do impôsto sôbre a propriedade territorial rural; consumo;

e) participação na arrecadação dos impostos de renda e de

f) participação na arrecadação dos impostos sôbre combustiveis liquidos e lubrificantes, energia elétrica e sôbre minerais;

g) taxas sôbre serviços municipais e

h) contribuição de melhoria.

Pela Emenda n 18, a partir de 1967, prazo prorrogável por mais dois anos (art. 26, $\S 1^{\%}$ ), desaparecerão o impôsto de consumo, substituido pelo impôsto sôbre produtos industrializados, e o impôsto sôbre vendas e consignações cujo nome será $d / 2$ impôsto sôbre a circulação.

Em que pese o grande sentido econômico da referida emenda constitucional, os Estados serão grandemente prejudicados com a nova discriminação de rendas, pois a grande fonte de receita estadual - o impôsto de vendas e consignações - embora cobrado com outro nome, sofreu sérias restrições que irão diminuir a sua produtividade. Tais restrições são:

a) a aliquota é uniforme para tôdas as mercadorias, não excedendo, nas operações que as destinem a outros Estados, o limite fixado em Resolução do Senado Federal; 
b) o impôsto não é cumulativo, abatendo-se em cada operação, nos têrmos do disposto em lei complementar, o montante cobrado nas anteriores, pelo mesmo ou por outro Estado, e não incidirá sôbre a venda a varejo diretamente ao consumidor de gêneros de primeira necessidade;

c) participação dos Municipios na arrecadação do impôsto nas transações realizadas dentro de sua área.

Por outro lado, os Municipios foram grandemente benieficiados com essa discriminação de rendas, pois, além das acima especificadas, terão a exclusividade da área remanescente, podendo criar outros tributos, tudo nos têrmos do artigo 15, da Emenda Constitucional $\mathrm{n}^{\circ} 18$, assim redigido:

Art. 15. Compete aos Municipios o impôsto sôbre serviço de qualquer natureza, não compreendido na competência tributária da União e dos Estados.

Parágrafo único. Lei complementar estabelecerá critérios para distinguir as atividades a que se refere êste artigo das previstas no artigo 12, que trata da competência dos Estados sôbre a cobrança do impôsto sôbre operações relativas à circulação de mercadorias, realizadas por comerciantes, industriais e produtores.

A Reunião dos Secretários de Fazenda dos Estados, realizada no Rio de Janeiro em junho de 1966, decidiu que o nôvo sistema tributário entrará em vigor a partir de 1 i de janeiro de 1967 , excetuada a vigência do impôsto de circulação sôbre Mercadorias que substituiu o impôsto de vendas e consignações, que seria, entretanto, escriturado nos livros comerciais de $1^{\circ}$ de janeiro a 30 de junho de 1967, a título de proporcionar estudos de amostragem do comércio e indústria, tendo em vista obter estatísticas mais realísticas para a fixação das aliquotas, permanecendo no primeiro semestre de 1967 a atual estrutura do impôsto de vendas e consignações.

Estima-se que o Fundo de Participação previsto na Emenda n० 18, que segundo os Secretários de Fazenda será o responsável nos pequenos Estados por cêrca de $25 \%$ da receita dos mesmos, entrará em vigor em janeiro de 1967, sendo a distribuição feita: $5 \%$ pela área territorial dos Estados e $95 \%$ combinando o contingente populacional com o coeficiente inverso da renda per capita .

A previsão do Fundo de Participação dos Estados para 1967. segundo cálculos dos técnicos do Ministério da Fazenda e pu- 
blicação do Jornal do Brasil de 18 de junho de 1966, é a seguinte:

\section{DISTRIBUIÇÃO DO FUNDO DE PARTICIPAÇÃO DOS ESTADOS}

ESTIMATIVA PARA 1967

Critério de Distribuição $\left\{\begin{array}{r}95 \% \text { com base na população-Renda e per capita s } \\ 5 \% \text { com base na superfície }\end{array}\right.$

\begin{tabular}{|c|c|c|c|}
\hline ESTADOS & $\begin{array}{l}5 \% \text { COM BASE NA } \\
\text { SUPERFICIE }\end{array}$ & $\begin{array}{c}95 \% \text { COM BASE NA } \\
\text { POPULAÇÃO } \\
\text { (RENDA PER CAPITA) }\end{array}$ & Cr\$ 1.000 .000 \\
\hline 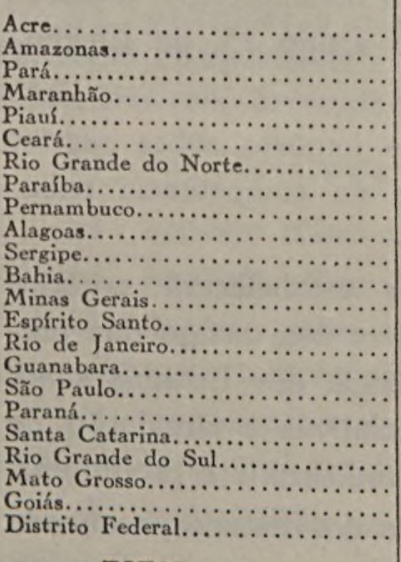 & $\begin{array}{r}463,2 \\
4.756,8 \\
3.794,4 \\
998,4 \\
760,8 \\
448,8 \\
160,8 \\
170,4 \\
300,0 \\
86,4 \\
69,6 \\
1.706,4 \\
1.785,6 \\
139,2 \\
129,6 \\
4,8 \\
753,6 \\
607,2 \\
292,8 \\
859,2 \\
3.744,0 \\
1.951,2 \\
16,8\end{array}$ & $\begin{array}{r}6.885,6 \\
6.885,6 \\
12.676,8 \\
32.740,8 \\
17.236,8 \\
40.492,8 \\
12.403,2 \\
18.012,0 \\
33.105,6 \\
13.771,2 \\
12.403,2 \\
52.713,6 \\
48.244,8 \\
11.035,2 \\
18.969,6 \\
6.885,6 \\
20.702,4 \\
23.256,0 \\
13.224,0 \\
22.070,4 \\
8.253,6 \\
19.836,0 \\
4.195,2\end{array}$ & $\begin{array}{r}7.348,8 \\
11.642,4 \\
16.471,2 \\
33.739,2 \\
17.997,6 \\
40.941,6 \\
12.564,0 \\
18.182,4 \\
33.405,6 \\
13.857,6 \\
12.472,8 \\
54.420,0 \\
50.030,4 \\
11.174,4 \\
19.099,2 \\
6.890,4 \\
21.456,0 \\
23.863,2 \\
13.516,8 \\
22.929,6 \\
11.997,6 \\
21.787,2 \\
4.212,0\end{array}$ \\
\hline TOTAL $\ldots \ldots \ldots \ldots \ldots$ & $24.000,0$ & $456.000,0$ & $180.000,0$ \\
\hline
\end{tabular}

